\title{
Standardy závěrečných prací pedagogických oborů
}

\author{
Jiří Němec \\ Masarykova univerzita, Pedagogická fakulta, Katedra sociální pedagogiky
}

Redakci zasláno 29. 4. 2013 / upravená verze obdržena 12. 8. 2013 / k uveřejnění přijato 13. 8. 2013

\begin{abstract}
Abstrakt: Téma kvality závěrečných prací obhajovaných na vysokých školách je v kontextu občasných plagiátorských kauz stále živé. Studie zkoumá dokumenty fakult (standardy), které se svým tématem a obsahem váží $\mathrm{k}$ závěrečným pracím. Analyzovanou jednotkou jsou dokumenty z prostředí fakult, ústavů (kateder), které v ČR garantují a zajišttují pedagogické obory. Výchozí pozicí pro studii je popis proměny současného kontextu, především přechod na dvoustupňové studium, vzrůstající počet studentů v terciárním vzdělávání v uplynulém desetiletí, důraz na kvalitu a learning outcomes $\mathrm{v}$ kontextu konceptu přístupu zaměřeného na studenta a celostátního projektu Q-RAM. Celkem bylo analyzováno 24 dokumentů prostřednictvím strukturní obsahové analýzy s využitím formálních, obsahových, typizujících a stupnicových forem analýzy. Výsledkem je rozkrytí struktury dokumentů, které nám následně umožnilo popis jejich hlavních charakteristik. Jedno ze zjištění dokládá převahu procedurálních charakteristik těchto dokumentů na úkor zdůraznění obsahových náležitostí a oborových standardů, které by studentům jasnou a srozumitelnou formou sdělovaly, co od nich daná instituce očekává. Závěr studie konstatuje, že se jedná o téma, které garantům pedagogických oborů otevírá prostor pro koncepční a tvůrčí práci při vytváření relace mezi kompetencemi absolventů, výstupů učení jednotlivých disciplín a potřebou formulovat smysluplný standard závěrečné práce daného oboru.
\end{abstract}

Klíčová slova: strukturní obsahová analýza, obsahová analýza dokumentů, standardy závěrečných prací, pedagogické obory, př́istup zaměřený na studenty, learning outcomes

V posledních několika letech jsme měli možnost sledovat mediální obraz kvality pečlivě vybraných závěrečných prací, které se obhajovaly na soukromých, ale též veřejných vysokých školách. Média přitom jednoznačně preferovala témata tzv. „urychlených studií“ mnohých politiků a poukazovala na možné mezery v zavedeném systému vysokoškolského vzdělání, především v procesu obhajoby a zveřejňování závěrečných prací, které jsou ve většině 
oborů podmínkou pro získání příslušného titulu. Poutavé a bulvárně lákavé nadpisy nás odkazovaly na situace, kdy některé obhájené práce nebylo možné dohledat, nebyly podle zákona zveřejněny, jiné sestávaly z několika málo stran nebo se jednalo o plagiáty, popř́ípadě nerespektovaly citační normu apod. Stávající mediální diskurs vyspěl do té podoby, že předmětem zájmu už není pouhá existence či neexistence práce samotné, ale její tzv. „kvalita“. Kdo ovšem může posoudit úroveň této kategorie? Právě do vypuknutí prvních mediálních kauz jsme se mohli oprávněně domnívat, že to budou právě akademici, kteří střeží poslední zbytky mravního étosu naší společnosti, a tudíž i dohlédnou, minimálně „,v̌̌ema čtyřma očima“, na požadovaný výstup. Obecně jsme přece vycházeli z tradičního předpokladu, že vysokoškolský pedagog ví, jakých kvalit by měla dosahovat závěrečná práce, a očekávali jsme také, že toto vnitřně ukotvené kritérium uplatní při hodnocení.

Předmětem našeho textu nebude hledání odpovědí na otázky spojené s př́ičinami takového jednání, ale prostřednictvím kvalitativní obsahové analýzy se pokusíme zmapovat, zda existují a popř́ípadě jaká je v prostředí českých vysokých škol ${ }^{1}$ (jednotlivých fakult, popř́padě kateder, ústavů) struktura dokumentů, které popisují formu, typ a kvalitu závěrečných prací. Naše směřování bude vedeno následujícími problémovými otázkami:

- Existuje v kontextu pedagogických oborů deklarativní vymezení požadavků (standardů) na závěrečné práce?

- Jakou strukturu tyto dokumenty mají a „co vlastně studentům ř́kají“ (jaký je jejich obsah, jaké je jejich sdělení)?

- Jak se vnitřní sdělení určité normy promítá do charakteru studovaného oboru, popř́padě jak je provázáno s výstupními kompetencemi absolventů?

Cílem naší výzkumné studie bude nejdříve popsat faktory ovlivňující celý proces tvorby a hodnocení závěrečných prací prostřednictvím dokumentů vydávaných fakultou nebo příslušným garančním pracovištěm (katedrou, ústavem, institutem apod.) a následně prostřednictvím analýzy obsahu dokumentů usměrňujících tento proces popsat základní charakteristiky,

Cíleně se zaměřujeme na analýzu dokumentů v kontextu českých vysokých škol. Pro analýzu analogických dokumentů pocházejících ze zahraničních univerzit se nám nepodařilo získat relevantní soubor (často nejsou veřejně přístupné) a hlavním motivem autora bylo mapování českého prostředí. 
které jsou typické pro tyto dokumenty, a přispět tím do odborné diskuse ke standardům závěrečných prací, metodologických standardů nevyjímaje.

\section{Kontext, realita a teorie}

Zájem médií o kvalitu závěrečných prací není klíčovou pohnutkou, která nás vede $\mathrm{k}$ analýze dokumentů, jež se váží k danému tématu. Samotnou přičinou, která by nás měla vést $\mathrm{k}$ zamyšlení nad výstupní kvalitou absolventů a potažmo jejich kvalifikační prací, je samotný kontext doby, na jejímž pozadí se proces terciárního vzdělávání uskutečňuje, a sociální faktory, které ho utvářejí.

\subsection{Počet studentů v terciárním vzdělávání = větší počet závěrečných prací}

Z dostupných statistických zpráv Českého statistického úřadu ${ }^{2}$ je patrné, že počet studentů v terciárním vzdělávání se v meziobdobí let 2001 a 2010 téměř zdvojnásobil ${ }^{3}, \mathrm{v}$ absolutních hodnotách to představuje nárůst z 204 tis. na 396 tis. studentů. V populaci dvacetiletých (v rozmezí 20-29 let) to je relativní nárůst z $12 \%$ na $27 \%$ mladých lidí. Tomuto trendu odpovídá i počet absolventů, který se v prezentovaném meziobdobí zvýšil z 30 tis. na 80 tis. studentů ${ }^{4}$. Teprve uplatnění kritéria kvality (od roku 2011/2012) při rozdělování finančních prostředků vysokým školám a striktní stanovování limitů počtů studentů pro jednotlivé typy studií tento trend zastavilo. Zdvojnásobení počtu studentů však vytvořilo tlak na změnu výukových forem a metod (např. masové zavádění e-learningových studijních opor, hromadné přednášky pro stovky studentů mnohdy na úkor seminární výuky apod.). Větší počet studentů klade vysoké nároky na udržení kvality výstupních prací a za předpokladu, že se také dvojnásobně nenavýšil počet akademických pracovníků (to by bylo ekonomicky neúnosné), dochází k jejich zvýšené pracovní zátěži.

\footnotetext{
Studenti a absolventi vysokých škol v roce 2010. Oficiální web ČSU, dostupné z http://www. czso.cz/csu/redakce.nsf/i/studenti_a_absolventi_vysokych_skol_v_cr_celkem/\$File/1_VS_ studenti_celkem_11.pdf

3 Odhlédněme nyní od situace devadesátých let minulého století, kdy se počet studentů v terciárním vzdělání pohyboval kolem $5 \%$.

4 Tento údaj však nemusí být zcela vypovídající, protože toto období bylo poznamenáno přechodem na tzv. dvoustupňové studium, tedy kromě absolventů magisterských programů rostl i počet bakalářù.
} 


\subsection{Větší počet studentů = jejich vyšší variabilita}

Větší počet studentů, kterým se na straně jedné otevírá cesta ke zvýšení kvalifikace a tím i lepšímu uplatnění na trhu práce, přináší terciárnímu vzdělávání na straně druhé nový prvek studijní variability studentů. Představíme-li si obecné rozložení schopností (především intelektu), které odpovídá Gaussovu normálnímu rozdělení, pak je patrné, že na vysokých školách již nestuduje elita z pravého konce zvonovitě se rozprostírajícího histogramu, ale studenti s průměrnými, $v$ mnohých případech i podprůměrnými předpoklady pro studium. ${ }^{5}$ Tento fakt sám o sobě nemusí znamenat nic špatného, situace se navíc liší v závislosti na studovaném oboru, protože vhodnou kompenzací tohoto fenoménu může být nejčastěji vnitřní silná motivace studentů a zájem o obor. Reálná situace je však taková, že pracujeme se širokým spektrem osobnostních charakteristik studentů, jako je úroveň intelektu, motivace $\mathrm{k}$ učení a učební styl, zájmu o obor, postoje k cílům studijního programu atd. To, co se dříve jevilo jako dostatečné vysvětlení, se může proměňovat v opakovanou mailovou komunikaci, která se mnohdy vzdaluje věcné podstatě odborného problému. Postoje mnohých akademiků do jisté míry nereflektují reálný stav a ke stávající populaci studentů přistupují obdobně jako v polovině devadesátých let minulého století, realita naznačená výše je však zcela odlišná. Právě $\mathrm{v}$ této souvislosti se nám jako vhodný jeví koncept tzv. přístupu zaměřeného na studenta (student centered teaching), o kterém pojednáme dále.

\subsection{Dvoustupňové studium = téměř dvojnásobný počet závěrečných prací}

Dalším faktorem, který zasahuje do kvality závěrečných prací a nevztahuje se pouze $\mathrm{k}$ faktu, že v posledním desetiletém mezidobí se počet studentů zdvojnásobil, jsou důsledky tzv. boloňského procesu, který se v českém prostředí začal plně uplatňovat od počátku nového tisíciletí, tedy v období výrazného růstu počtu studentů. Převážná většina oborů restrukturalizovala kurikulum do dvou stupňů, bakalářského a navazujícího magisterského. Hlavním problémem ovšem nebylo kurikulární uspořádání jednotlivých disciplín, jejich provázanost a prostupnost, ale v mnoha případech nalezení smysluplných výstupních kompetencí (profilu absolventa) studentů bakalářského stupně (především v učitelských oborech) a s ním i adekvátní provázanost s bakalář-

5 To je patrné např̀ z tzv. Zpráv o výsledku prijijímacího ř́zení, které vysoké školy ze zákona zveřejňují, a jsou tudíž snadno dostupné. Viz např. Zpráva Masarykovy univerzity dostupná z http://www.muni.cz/admission/bachelor_reports?lang=cs. Z ní vyplývá, že pro přijetí na některé obory je dostatečné umístění i pod desátým percentilem. 
skou prací. Před akademiky se objevil nový úkol, kromě již etablované diplomové práce, zaměřit se na definici významu bakalářských prací, vytipování vhodných témat, metodologických postupů apod. Dále se pokusíme naznačit, zdali se tento fakt promítl do analyzovaných dokumentů, existují-li rozdíly v pojetí mezi diplomovými a bakalářskými pracemi. Zdvojnásobení závěrečných prací nebyl jediný důsledek boloňského procesu. „Změna tváře univerzity“, jak v kontextu neoliberalismu zmiňují Kaščák s Pupalou (2012, s. 128 a dále), se dotýká i procesu benchmarkingu vysokých škol prostřednictvím různých parametrů výkonu, evaluace studijních programů, změn ve financování výzkumu a dotýká se též procesu standardizace (touze po standardech závěrečných prací), která je pro neoliberální diskurz charakteristická.

\section{$1.4 Q-R A M$}

Popis kontextu uzavíráme zmínkou o tzv. Q-RAM - Národním kvalifikačním rámci terciárního vzdělávání $v$ ČR, který vznikal v posledních třech letech a do jehož př́pravy byli zapojeni i zástupci vysokých škol.

Cílem zavádění kvalifikačních rámců je zvýšit přehlednost, a tudíž i prostupnost vzdělávacích soustav v národním i mezinárodním kontextu. Kvalifikační rámce se zaměřují na výsledky učení, tedy na skutečné znalosti, dovednosti a způsobilosti absolventů, na rozdíl od tradičních popisů vzdělávacích soustav, založených na výčtu formálních ukazatelů, jako jsou délka studia nebo povinné předměty. (Černikovský \& Nantl, 2011, s. 6)

Obsahem kvalifikačního rámce není pouze úroveň kvalifikace (level), zmiňující charakteristiky bakalářského, navazujícího magisterského a doktorského stupně, ale také např. studijní zátěž (workload), popisující časovou dotaci předmětů, bloků a zejména počtu kreditů, a především definice tzv. výstupů z učení (learning outcomes). Tato definice zahrnuje jasné, srozumitelné a především měřitelné vyjádření znalostí, dovedností a dalších profesních kompetencí, které se vztahuje jak k jednotlivým předmětům, výukovým blokům, kurzům apod., tak především k celým oborům. V souladu s kvalifikačním rámcem je tedy zcela přirozené, abychom uměli vymezit nároky kladené na závěrečné práce, které jsou jedním z klíčových výstupů určitého stupně terciárního vzdělávání.

\subsection{Př́stup zaměřený na studenta}

$\mathrm{V}$ kontextu výše uvedeného je vhodné zmínit tzv. koncept př́stupu zaměřeného na studenta, který je uplatňován na některých západních univerzi- 
tách a který koresponduje $s$ naším tématem. Jedná se o specifický koncept vycházející z humanistické psychologie C. Rogerse a z tzv. personal centered approach $^{6}$ (přístupu zaměřeného na člověka - klienta). Ve své teorii kladl důraz na existenci a svobodu. Na JÁ nahlížel z procesního hlediska jako na určitý konstrukt, který se může měnit ${ }^{7}$, a to v prostředí určitých společenských norem, ale přitom ve svobodném prostředí (srov. Drápela, 1997, s. 124). Možná se nám může zdát tato teorie odtržená od vlastní podstaty tématu, ale pokud ji hlouběji analyzujeme, analogicky ji můžeme vztáhnout $\mathrm{k}$ vysokoškolskému svobodnému prostředí, ve kterém studentům nabízíme určité pohledy (paradigmata, teorie, přístupy) na jevy kolem nás, ale definujeme též minimum určitých pravidel např̀ v podobě standardů apod. Relativně známá a často citovaná (viz např. Kratochvíl, 1998, s. 56) triáda zásad (empatické porozumění klientovým pocitům, úplné přijetí - akceptace klienta a kongruence - plná autenticita terapeuta), která by měla být dodržována, aby byla psychoterapie účinná, se postupně transformovala do oblasti vzdělávání, kde se rozvíjí jako př́stup zaměřený na studenta (student centered teaching). Koncept se opírá o myšlenku, která se v pedagogickém myšlení postupně rozvíjí již od počátku 20. století a zdůrazňuje partnerství a rovnost mezi učitelem a studentem, přičemž vyučující reflektuje individuální potřeby studenta a snaží se ve spolupráci s ním volit adekvátní výukové strategie a metody a dospět ke společným cílům. Právě zdůrazňování potřeby empatie, akceptace studenta a hledání odpovídajících výukových metod koresponduje se zmíněnou variabilitou studentské populace. $V$ reakci na tuto realitu jsou klíčové výukové strategie akademiků, prostřednictvím kterých volíme relevantní výukové prostředky, metody a konkrétní formy evaluace a snažíme se o to, aby zvolené př́istupy zrcadlily definované výstupy učení. Již zmínění autoři (Černikovský \& Nantl, 2011) k tomu uvádějí:

Kvalita kvalifikace je zajiš̌ována především tzv. konstruktivním propojením (constructive alignment) stanovených výstupů z učení, forem a metod výuky a učení a metod hodnocení. Jde o to, že formy a metody výuky a učení mají být navrženy tak, aby co nejlépe podporovaly dosažení očekávaných výstupů (např. je-li očekáváno, že student prokáže schopnost argumentovat,

V původní koncepci a podle názvu původního díla z roku 1951 client-centered therapy.

Prosím, věnujme pozornost významu slovního spojení „může měnit“, ve kterém je kladen důraz na potenciál pacienta (studenta), a „můžeme ho měnit“, v rámci kterého by byl kladen důraz na možnou manipulaci s klientem (studentem) ze strany terapeuta (učitele). Rogers odmítal behavioristický přístup. 
nejvhodnější formou výuky patrně nebude přednáška); stejně tak metody hodnocení mají adekvátně ověřovat výstupy, které byly stanoveny a jež se podle zvolených forem a metod výuky a učení student skutečně mohl naučit (napřs schopnost spolupráce $v$ týmu může být podpořena kombinací semináře a vysoké míry autonomního učení, se zpracováním skupinového projektu jako podkladu pro hodnocení). (Černikovský \& Nantl, 2011, s. 13)

V rámci našeho tématu však musíme připomenoutještě další aspekt odrážející partnerský přístup, který bychom mohli vyjádřit prostřednictvím jasného definování očekávání vyučujících od studentů. Jedná se např. o přesná a jasná zadání seminární práce nebo cvičení, ze kterých je nejen patrné, jakou práci má student vytvořit, ale jaké cíle jsou tím sledovány a jaká jsou např́íklad kritéria hodnocení. Podobně též u závěrečných prací, ve kterých se syntetizují získané dovednosti z jednotlivých disciplín, ale studenti prostřednictvím nich prokazují naplnění požadovaných kompetencí daného oboru.

\section{Dokumenty vztahující se k závěrečným pracím a jejich analýza}

Vzhledem k tématu, charakteru problémových otázek a cílům výzkumu jsme jako hlavní výzkumnou metodu zvolili obsahovou analýzu. Ta nám umožňuje proniknout do hloubky jednotlivých dokumentů, popsat strukturu, definovat klíčové kategorie, zprostředkovat jazyk (též např. jeho sémantiku, sémiotiku znaků), kterým dokument komunikuje s jeho recipienty, přičemž vlastních technik, jak přistoupit k analýze textu, je celé spektrum (srov. Mayring, 2003, s. 43). Jako nejvhodnější jsme zvolili techniku strukturace.

Než přistoupíme k popisu analyzované jednotky, zpřesníme naše výzkumné zaměření prostřednictvím otázek, které jsme rámcově vymezili již v úvodu textu. Zajímalo nás:

- Jakou strukturu mají dokumenty vztahující se k závěrečným pracím a jaké evaluační standardy studentům představují?

- Prostřednictvím jakých kategorií je dokument tvořen a jakou vazbu mají tyto kategorie ke standardu závěrečných prací?

- Obsahují dokumenty formulaci očekávání, která mají být realizací závěrečné práce naplněny? ${ }^{8}$

8 Především v kontextu zmíněného přístupu zaměřeného na studenta a vztahujícího se ke kritériu jasného sdělení očekávání, které má být realizací závěrečné práce naplněno. 
Abychom mohli odpovědět na všechny otázky, vymezili jsme analyzovanou jednotku, která bude podrobena zkoumání. $V$ našem případě a ve vztahu k výzkumným problémům se jedná o množinu dokumentů, které mají asociaci k pedagogickým oborům a popisují problematiku závěrečných prací. Vzhledem k oborovému zaměření časopisu a zejména tohoto monotematického čísla jsme zaměřili náš výběr na dokumenty, které se vztahovaly k závěrečným pracím pedagogických oborů studovaných na vysokých školách v ČR. Do pedagogických oborů jsme v nejširším slova smyslu zařadili pedagogiku, sociální pedagogiku, pedagogiku volného času a vychovatelství; Q-RAM tyto obory sdružuje v kategorii, kterou označuje jako „neučitelskou pedagogiku“.9 $\mathrm{Na}$ základě takto definovaného okruhu oborů jsme dále mohli přistoupit k vymezení institucí, kde jsou tyto programy realizovány. Při samotném sběru dokumentů jsme čerpali z dostupných veřejných zdrojů, zejména oficiálních webů fakult a kateder, jež obor realizují a garantují. V př́ípadech, kdy jsme očekávaný dokument nenalezli, oslovovali jsme odpovědné pracovníky a snažili se ho vyžádat prostřednictvím mailu. ${ }^{10}$ Primárně pro nás byly důležité dokumenty, které mají úzkou vazbu na studijní obor, ve kterém mohou být zohledněna konkrétní specifika vycházející z profilu absolventa. Pokud nebyly k dispozici, zařadili jsme do souboru obecnější dokumenty s celofakultní platností. Seznam analyzovaných dokumentů je součástí přílohy (přehled analyzovaných dokumentů).

Výše uvedeným postupem se nám podařilo shromáždit celkem 24 dokumentů vztahujících se $\mathrm{k}$ problematice přípravy, popřípadě i hodnocení závěrečných prací, a to celkem ze čtrnácti institucí. ${ }^{11}$ Pouze ve třech případech se jednalo o dokumenty katedry (ústavu), které měly bezprostřední vazbu ke garantovanému a rozvíjenému oboru, v ostatních případech se jednalo především o tzv. pokyny nebo směrnice (opatření apod.) děkana bez zjevné diferenciace oborů, které fakulta nabízí. Potěšujícím zjištěním bylo, že veškeré dokumenty byly relativně aktuální, datované pravděpodobně ve stávajícím funkčním období děkanů a děkanek.

Jak jsme uvedli výše, $\mathrm{k}$ analýze dokumentů jsme přistoupili prostřednictvím techniky strukturace. Jejím cílem je podle Mayringa (2003, s. 82-83) „vytvo-

\footnotetext{
Z této kategorie jsme pro naši analýzu vyloučili obor speciální pedagogika.

10 Dokumenty jsou obvykle veřejně dostupné, $\mathrm{v}$ některých př́ípadech jsou součástí e-learningových kurzů.

11 Za instituci v tomto případě považujeme fakultu, popřípadě katedru nebo ústav, jednalo-li se o standardy vztahující se prŕmo k oboru.
} 
řit z analyzovaného materiálu strukturu, která koresponduje s výzkumnými otázkami a uplatňuje systém kategorií". Analýza přitom obsahuje následující tři celky: definici kategorií, ilustrativní (stanovené) příklady a pravidla kódování. Ve vztahu k procesu kódování jsme analyzované dokumenty opakovaně pročítali a zvýrazňovali klíčové pojmy obsažené v odstavcích, popř́ípadě i nadpisech a podnadpisech určitých dokumentů, které byly sémanticky relevantní k námi definovaným cílům, tzn. popisovaly kvantitativní nebo kvalitativní vlastnosti či určité povinně vyžadované charakteristiky závěrečné práce. Tyto kódy jsme následně sdružili do dvou kategorií, přičemž vlastním kritériem byla „vidovost“ popisované činnosti nebo stavu. Identifikované kódy jsme rozdělili do dvou kategorií na ty, které popisují určitou proceduru („co se má dělat"), a určitý výsledný stav - cíl („co má být uděláno“), přičemž druhou kategorii jsme rozšířili ještě o dvě podkategorie sdružující pojmy formální a obsahové vztahující se k cílovému stavu. Příklady konkrétních pojmů, které se staly předmětem naší analýzy, stejně tak i vytvořené kategorie a podkategorie, jsou součástí tabulky 1.

Tabulka 1

Analýza struktury dokumentů - ukázka

\begin{tabular}{|c|c|c|}
\hline \multirow{2}{*}{ PROCEDURÁLNÍ - „co se má dělat" } & \multicolumn{2}{|l|}{ CÍLOVÉ - „co má být uděláno“ } \\
\hline & FORMÁLNÍ & OBSAHOVÉ \\
\hline $\begin{array}{l}\text { Volba tématu, zadání, projekt, } \\
\text { vložení elektronické verze, } \\
\text { odevzdání tištěné verze, převod } \\
\text { do PDF formátu, podmínky } \\
\text { zveřejnění, počet exemplářů, } \\
\text { průběh obhajoby, termíny a jejich } \\
\text { návaznosti, registrace předmětů } \\
\text { navázaných na závěrečnou práci, } \\
\text { kreditové ohodnocení, semináře } \\
\text { k závěrečné práci (ZP), definice } \\
\text { odpovědností v procesu přípravy } \\
\text { ZP, kontrola zveřejnění prací. }\end{array}$ & $\begin{array}{l}\text { Prohlášení autora, citační } \\
\text { norma, abstrakt, anotace, } \\
\text { požadavky na stylistický, } \\
\text { jazykový a odborný styl, rozsah } \\
\text { BP, rozsah DP, podmínky } \\
\text { užití části textu BP pro DP, } \\
\text { okraje, číslování, formátování } \\
\text { textu, etická norma, titulní } \\
\text { strana, typy prací (historicko- } \\
\text { srovnávací, deskriptivní, } \\
\text { empiricko-výzkumné, } \\
\text { filozofické, prognostické), } \\
\text { požadavky na závěr ZP } \\
\text { (obsahové, metodologické, } \\
\text { praktické využití poznatků). }\end{array}$ & $\begin{array}{l}\text { Naplnění profilu } \\
\text { absolventa TF JČU, } \\
\text { standard, odlišení } \\
\text { mezi BP a DP (použito } \\
\text { kritérium Bloomovy } \\
\text { taxonomie), obsahové } \\
\text { požadavky na práce } \\
\text { teoreticko-empirické, } \\
\text { teoreticko-aplikační, } \\
\text { vyjádření vlastního } \\
\text { názoru, obsahová } \\
\text { návaznost tématu } \\
\text { na obor, standardy } \\
\text { metodologické. }\end{array}$ \\
\hline
\end{tabular}

Při analýze dokumentů jsme se dále nechali vést možnými formami strukturace, jak je popisuje Mayring (2003, s. 85-94). Prostřednictvím formální strukturace je patrná skladba (struktura) dokumentů, které velký 
prostor věnují popisu procesů (viz tabulka výše). Například: jak má začít př́prava ZP, které předměty si studenti mají zapsat, na koho se obrátit, kam zvolené téma vložit, jaké jsou časové konsekvence apod. Následně vyjadřují určitý cílový stav prostřednictvím formy, např. jaký má být rozsah, jaká má být užita citační norma, požadavky na jazykový styl apod. Následně a bohužel okrajově zmiňuje cílový stav z hlediska obsahu, např. užití vlastního názoru, užití vybrané výzkumné metody apod. Prostřednictvím obsahové strukturace se $\mathrm{v}$ podstatě dozvídáme o zastoupení jednotlivých témat $\mathrm{v}$ analyzovaných dokumentech, jinými slovy vybraných kódů umístěných do jednotlivých kategorií, jež vypovídají o tom, co dokumenty studentům ř́kají, jaký typ informací a požadavků jim sdělují. Typizovaná strukturace bude patrná především z následujícího textu, ve kterém jsme se snažili citovat vybrané charakteristické (markantní) rysy dokumentů, a stupnicová strukturace, jak název napovídá, nám umožnila vytvořit dimenzionální škálu, prostřednictvím které jsme získali představu o kvantitativním zastoupení poměru jednotlivých kategorií. Vytvoř́me-li tedy v rámci stupnicové strukturace pomyslnou škálu, pak levý konec kontinua bude obsahovat pojmy (kategorie) charakterizující proces (proceduru spojenou s přípravou ZP), pravý pak cíle, kterých má být dosaženo (nejdříve formální a následně obsahové). Zastoupení charakteru obsahu (pojmů, vyjadřující specifické pokyny či požadavky) v jednotlivých kategoriích, vytvořené na základě analýzy a kvalifikovaného odhadu, nám umožňuje udělat si určitou představu o povaze analyzovaných dokumentů:

- Charakteristika procedurálních postupů: 50-60 \%

- Charakteristika formálních náležitostí cílového stavu: 30-40 \%

- Charakteristika požadovaných vlastností ZP - standardů z hlediska obsahu: $10-20 \%$

Pokusme se nyní shrnout poznatky analýzy a odpovědět na zvolené otázky.

\subsection{Co dokumenty studentům ř́kají, jaká je jejich struktura}

Vzhledem k povaze analyzovaných dokumentů (viz výše) můžeme obecně říct, že v nich převažují „procedurální charakteristiky“, které jsou společné téměř všem dokumentům a které více než na vlastní podstatu (smysl a cíle) závěrečné práce se zaměřují na popis procesu vztahujícího se k volbě tématu nebo tzv. zadání, způsobu evidence, odevzdávání a ukládání do rozličných elektronických systémů a databází, způsobu užívání citačních norem, definici 
rozsahu, velikosti okrajů a podobě titulní strany, návaznosti na další semináře vztahující se k závěrečným pracím, počtům kreditů za související semináře atd. Aniž bychom chtěli zlehčovat význam těchto typů informací, které mají své opodstatnění v daném univerzitním či fakultním systému a jsou důležité ve vztahu k dodržování zákonných povinností a evidenci studia, nemůžeme přehlédnout, že jsou ve vztahu k profesním kompetencím studentů pedagogických oborů často jediným dokumentem. V této souvislosti se nabízejí otázky. Jak jsou zohledněna specifika oborů uvnitř fakult? Jak se budou věcně lišit tzv. výstupy z učení závěrečné práce vychovatele, sociálního pedagoga nebo učitele historie, fyziky a výtvarné výchovy? Popis formálního procesu je jistě důležitý, ale dle našeho mínění nemůže nahradit diferencovaný popis cílů, očekávání, způsobu zpracovaní (metodologie) zvoleného tématu ve vztahu k danému oboru. Právě těmto aspektům se věnují dokumenty, které byly v naší analyzované jednotce zastoupeny ojediněle.

Obecné cíle nalezneme hned v několika dokumentech. S trochou nadsázky je můžeme označit jako „deštník“, pod který se schovají obory technické, př́írodovědné i humanitní, obtížně v nich nalezneme specifika pedagogických oborů. Např „Student prokazuje (...) schopnost aplikovat teoretické znalosti, dovednosti a kompetence, které získává a rozvíjí v průběhu studia na FP TUL.“12 Jiným př́kladem může být citace: „Účelem závěrečné práce je ověřit vědomosti a dovednosti studenta získané v průběhu studia a schopnost tvůrčím způsobem jich využít při řešení úkolu stanoveného zadáním práce."13 Př́íklad, který se blíží opačnému konci kontinua, nevyjadřuje se ke konkrétnímu cíli oboru, ale odvolává se již na profil absolventa, můžeme uvést z Teologické fakulty Jihočeské univerzity.

Smysl (...) práce spočívá právě v prokázání, že si student osvojil potřebné schopnosti, dovednosti, znalosti, hodnoty či postoje, které tvoří profil absolventa a jsou komunitou daného oboru oceňovány a považovány za rozlišující znaky profesionality. Konkrétněji řečeno, autor závěrečné práce musí prokázat, že se ve zvoleném oboru orientuje, osvojil si oborové myšlení a dokáže, na př́kladu vybraného problému, který $\mathrm{v}$ závěrečné práci zkoumá, na odborné úrovni komunikovat. (Veber \& Bauman, 2010, s. 9)

12 Pokyny pro zpracování bakalářské práce dostupné z http://www.fp.tul.cz/student/studiumna-fp/zaverecne-prace/pokyny-pro-zpracovani-bp

13 Pravidla zadávání závěrečné práce a jejích vypracování (rozhodnutí děkana č. 17/2009), dostupné z http://www.uhk.cz/cs-cz/studium/kvalifikacni-prace/zakladni-informace/ Stranky/default.aspx 


\subsection{V čem jsou dokumenty odlišné}

V analyzovaném souboru jsme identifikovali odlišné oblasti, které evokují dvě otázky. Jak je konkrétně realizován proces volby tématu závěrečné práce a jak je zohledněna úroveň odlišnosti bakalářského a magisterského stupně?

Je-li předmětem dokumentů otázka volby tématu, pak se setkáváme s dvěma přístupy, přičemž první z nich můžeme označit jako tradiční a druhý jako inovativní. Tradiční přístup operuje s pojmem a procesem, který je v textech popisován jako zadání závěrečné práce, zatímco druhý přístup je založen na tvorbě projektu závěrečné práce. Odlišnosti obou konceptů jsme shrnuli v následující tabulce a pokusili se je rozšířit i o požadavky na studenta.

\section{Tabulka 2}

\section{Komparace konceptu „zadání“ a „projektu“}

\begin{tabular}{ll}
\hline Zdání závěrečné práce & Projekt závěrečné práce \\
\hline $\begin{array}{l}\text { Student obvykle vybírá z nabízených témat } \\
\text { pro zpracování ZP. }\end{array}$ & $\begin{array}{l}\text { Student si volí vlastní téma vzhledem } \\
\text { k profesním zájmům a oboru, sekundárně } \\
\text { vybírá z nabízených témat. }\end{array}$ \\
\hline $\begin{array}{l}\text { Vyučující formuluje zadání - úkol, definuje } \\
\text { cíle a navrhuje i metody zpracování (naplnění } \\
\text { cílů). }\end{array}$ & $\begin{array}{l}\text { Student připravuje projekt, jehož obsahem } \\
\text { je popis problému, cíle práce a metody } \\
\text { zpracování (výzkumu). }\end{array}$ \\
\hline $\begin{array}{l}\text { Aktivita (i zodpovědnost) je více na straně } \\
\text { pedagoga, který je podle některých norem }{ }^{14}\end{array}$ & $\begin{array}{l}\text { Aktivita, zodpovědnost je na straně studenta, } \\
\text { který téma konzultuje s potenciálním } \\
\text { zodpovédnýím, volba tématu v rámci oboru je pak } \\
\text { i součástí obhajoby ZP. }\end{array}$ \\
\hline $\begin{array}{l}\text { Pasivnější student - versus - aktivnější } \\
\text { a zodpovědnější vedoucí práce v roli } \\
\text { pedagoga. }\end{array}$ & $\begin{array}{l}\text { Aktivnější a zodpovědný student - versus - } \\
\text { pasivnější vedoucí v roli supervizora. }\end{array}$ \\
\hline $\begin{array}{l}\text { Student postupuje dle zadání, které obdržel, } \\
\text { uplatnění konvergentního myšlení - } \\
\text { dodržování předem vytyčeného postupu, } \\
\text { oslabení prostoru pro tvořivost studenta. }\end{array}$ & $\begin{array}{l}\text { Student projektuje vlastní postupy a způsob } \\
\text { zpracování - uplatnění divergentního } \\
\text { myšlení, větší prostor pro kreativitu studentů. }\end{array}$ \\
\hline
\end{tabular}

Ve výčtu obou př́istupů bychom mohli pokračovat, ale pro naznačení odlišných konceptů, tedy přístupů ke studentovi z hlediska požadavků a výstupů učení, je výčet dostačující. Musíme též doplnit, že oba přístupy z levého či pravého spektra tabulky nejsou v praxi (v analyzovaných dokumentech) vyhraněné,

14 „Za formulaci tématu a podmínek vypracování závěrečné práce v obou případech odpovídá vedoucí práce..." (...) „Student požádá o zadání tématu vedoucího práce, který jej vypsal, popř. je ochoten vypsat." Viz norma pod výše uvedenou poznámkou. 
mnohdy se jedná o kombinaci obou, a v praxi pak nalezneme pracoviště, které se více hlásí $\mathrm{k}$ jednomu nebo druhému. Přístup z levého spektra bychom také mohli označit za "bezpečnější" - je více pod kontrolou vedoucího, z druhé strany pak „experimentálnější“ - je více (nebo bychom si to alespoň přáli) pod kontrolou studenta.

Druhá otázka spojená s odlišností bakalářské a magisterské úrovně nás jednak zavádí znovu k vymezení cílů a následně k odlišení obsahu, který by měl s cíli korespondovat. V obecných dokumentech nenalezneme významnější odlišení cílů bakalářské a diplomové práce. Pokud přece jen, jedná se většinou o drobné formulační odlišnosti, např $\mathrm{v}$ jednom $\mathrm{z}$ dokumentů se v kategorii přehled aktuálního stavu uvádí u BP „vymezení (výzkumného) problému s ohledem na aktuální stav zkoumání v dané problematice“, u DP „uvedení relevantních teorií a výsledků empirických výzkumů, jejich analýza, komparace, zhodnocení". 15

Dobrý př́iklad odlišení bakalářské a magisterské úrovně je patrný ze standardu, který ji popisuje prostřednictvím charakteristiky druhů prací. ${ }^{16} \mathrm{U}$ bakalářských prací jsou povoleny výzkumné sondy a dokument dále vysvětluje jejich strukturu a typ (survey, sekundární analýza dat, strukturované pozorování, obsahová analýza), dále pak teoreticko-aplikační práce (projekty rozvojového charakteru a vzdělávací modul nebo vzdělávací akce). V magisterské úrovni jsou požadována výzkumná šetření (detailně jsou definovány podmínky pro teoretickou, metodologickou a interpretační část), teoretickoaplikační práce a teoretické práce. U všech typů prací nalezneme také detailní popis očekávání, např. věcná kritéria pro práci s odbornou literaturou, sběr a rozsah dat, použití výzkumných metod apod.

Na celofakultní úrovni může být inspirující Metodická pomůcka ke zpracování závěrečných prací (Veber \& Bauman, 2010), která popisuje nejen možné typy prací $\mathrm{v}$ bakalářském nebo magisterském studiu, ale definuje je prostřednictvím očekávání. Jako kritérium pro posouzení naplnění očekávání a odlišení bakalářské a magisterské úrovně slouží revidovaná verze Bloomovy taxonomie. Zatímco pro bakalářskou úroveň je postačující úroveň vztahující

15 Příloha č. 1 - Obsahové náležitosti kvalifikačních prací, Směrnice děkanky PdF UP v Olomouci, dostupné z http://www.pdf.upol.cz/fileadmin/user_upload/PdF/prov-normy-dekana/ 2011/2S_2011_smernice_ke_szz_1.pdf

16 Standard pro písemné práce $k$ bakalářské zkoušce na Ústavu pedagogických věd FF MU, Standard pro písemné práce $k$ magisterské zkoušce na Ústavu pedagogických věd FF MU. Dostupné z http://www.phil.muni.cz/wupv/home/studium/pisemne-prace/pp/ 
se k práci s poznatky, koncepty, teoriemi apod., magisterská úroveň vyžaduje dovednosti spojené s intepretací, aplikací, konceptualizací, hodnocením apod. Jedná se o komplexní materiál, který přestože je určen všem oborům Teologické fakulty JU v Českých Budějovicích, nabízí hlubší vhled i do kritérií hodnocení a otevírá prostor pro doplnění oborových specifik.

\section{Závěrečná diskuse}

Původním smyslem uvažované analýzy bylo představit standardy závěrečných prací, které jsou uplatňovány v rámci pedagogických oborů v ČR. Záměrem bylo komparovat odlišnosti a jednotlivá specifika a shromáždit podnětný materiál pro garanty oborů (pracoviště) apod. Provedená analýza však naznačuje, že jediným, spíše formálním regulativním prvkem v oblasti tvorby a posuzování závěrečných prací jsou normy na úrovni fakult, nikoliv jednotlivých oborů (až na uváděné výjimky). Neexistuje tudíž smysluplná asociace ke specifikům pedagogických oborů, např̀ $\mathrm{k}$ jejich profilacím nebo zaměřením.

Analyzované dokumenty tedy nediferencují výstupy učení a úroveň bakalářských a magisterských studentů. Často při koncepci bakalářského studia uvažujeme o profesních kompetencích absolventa, ale dostatečně nevyužíváme možnosti profesně orientovat bakalářské práce. Pouze jediný výše citovaný příklad dokládá, že bakalářské práce mohou mít i metodický a rozvojový potenciál. Je to ideální př́ležitost, jak může budoucí pedagog doložit schopnost koncipovat výchovné a vzdělávací projekty prostřednictvím rozmanité škály metod, které daný obor nabízí. Naopak magisterské práce mohou být více zaměřeny na dovednosti studentů vycházející ze schopnosti užívat výzkumné nástroje, analyzovat a interpretovat data, kriticky přistupovat k teoretickým zdrojům, analyzovat dané teorie a aplikovat jejich poznatky do pedagogické a vědecké práce apod.

Dostatečně nejsou popsány cíle závěrečných prací. Dokumenty se omezují na obecná konstatování o prokázání vědomostí a dovedností. Stanovení cílů, očekávání ze strany pedagogů nám teprve sekundárně otevírá cestu k definování standardů. Popis určitého „třeba i ideálního“ cílového stavu a způsob hodnocení (komparace vůči standardům) považujeme za korektní a férový př́stup ve vztahu ke studentovi v kontextu výše uvedeného přístupu zaměřeného na studenta. Obtížně můžeme akceptovat argumentaci, se kterou jsme se v rámci šetření setkali, „že přece každý akademický pracovník ví, jak má závěrečná práce vypadat". Jasné definování výstupů učení a standardů nabízí 
velký rozvojový potenciál pedagogickým oborům. Analyzované dokumenty s odkazem na výše citovaný koncept jsou vůči studentům vstř́ícné v popisu formálních procedur a požadavků, velké rezervy mají v oblasti konkrétních obsahových sdělení a oborových standardů.

Větší pozornost věnují fakultní dokumenty problematice užívání citačních norem a „varováním“ před plagiátorstvím. Je patrné, že události popisované v úvodu se promítly i do nejrůznějších opatření představitelů fakult. Dokumenty také často zavazují vyučující povinnostmi a odpovědností, která by měla být směřována ke studentovi. Zvláště ve svobodném prostředí univerzit by měl mít student dostatek důvěry a možnosti vlastní volby, např. v podobě vytváření vlastních projektů více než uplatňování postupů dle „zadání".

Vrátíme-li se v závěru k úvodním otázkám, pak s akceptovatelnou mírou nepřesnosti, která je spojena s každým procesem zobecnění, můžeme konstatovat, že $\mathrm{v}$ rámci pedagogických oborů (až na uvedené výjimky) neexistuje dostatečné deklarativní vymezení standardů závěrečných prací. Pro pedagogickou komunitu to může být dobrou př́ležitostí, jak zkvalitnit přípravu svých studentů (absolventů). Analyzované dokumenty více než specifika oboru (druhy prací, požadované metodologické přístupy, očekávané výstupy apod.) popisují proceduru fakultního systému, proces, který je na všech fakultách obdobný. Studentům více představují formální postupy a cíle než obsahová specifika. Podobně i vztah mezi normou (až na uváděné výjimky) a výstupními kompetencemi absolventů v podstatě neexistuje.

\section{Literatura}

Černíkovský, P., \& Nantl, J. (2011). Národní kvalifikační rámec terciárního vzdělávání. Národní deskriptory. Praha: MŠMT.

Drápela, V. J. (1997). Přehled teorií osobnosti. Praha: Portál.

Kaščák, O., \& Pupala, B. (2012). Škola zlatých golierov. Vzdelávanie v ére neoliberalizmu. Praha: SLON.

Kratochvíl, S. (1998). Základy psychoterapie. Praha: Portál.

Mayring, P. (2003). Qualitative Inhaltsanalyse. Grundlagen und Techniken. Weinheim und Basel: Beltz Verlag.

Veber, T., \& Bauman, P. (2010). Metodická pomůcka ke zpracování závěrečných prací. Dostupné z http://www.tf.jcu.cz/getfile/08e7dfe316146697 


\section{Autor}

doc. PhDr. Jiří Němec, Ph.D., Masarykova univerzita, Pedagogická fakulta, Katedra sociální pedagogiky, Poříćí 31, Brno 603 00, e-mail: nemec@ped.muni.cz

\section{Educational subjects and the quality of final theses}

Abstract: The issue of quality of final theses defended at universities seen in the light of recent plagiarism cases still seems to be urgent. The study examines the faculty documents (standards) that are closely linked (by topic or content) to the final theses. The research sample comprises the faculty documents, and documents of the departments that educate prospective teachers. The point of departure for the study is the description of the present context transformation, especially the transformation into a two level study at universities, increased number of students in the tertiary study programmes in the past ten years, and emphasis placed on the quality and learning outcomes as seen from the point of view of student oriented approach as described in the national Q-RAM project. In the study, 24 documents were analysed through structural content analysis using formal, content, typological and scale analysis. This allowed us to understand the structure of the documents and thus to describe their main features. The results illustrate the prevailing procedure orientation of the documents, which corresponds with the lack of clear content focus and lack of definition of the subject-specific standards that would, in a simple and clear manner, introduce the students to what their institution expects of them. The study concludes that the addressed issue will allow the subject guarantees to define the relationship between the competences of the graduates, learning outcomes of the particular subjects and the need to articulate meaningful standard of the final work in the defined subject or field.

Keywords: structural content analysis, content analysis of documents, final theses standards, educational subjects, student centred approach, learning outcomes 


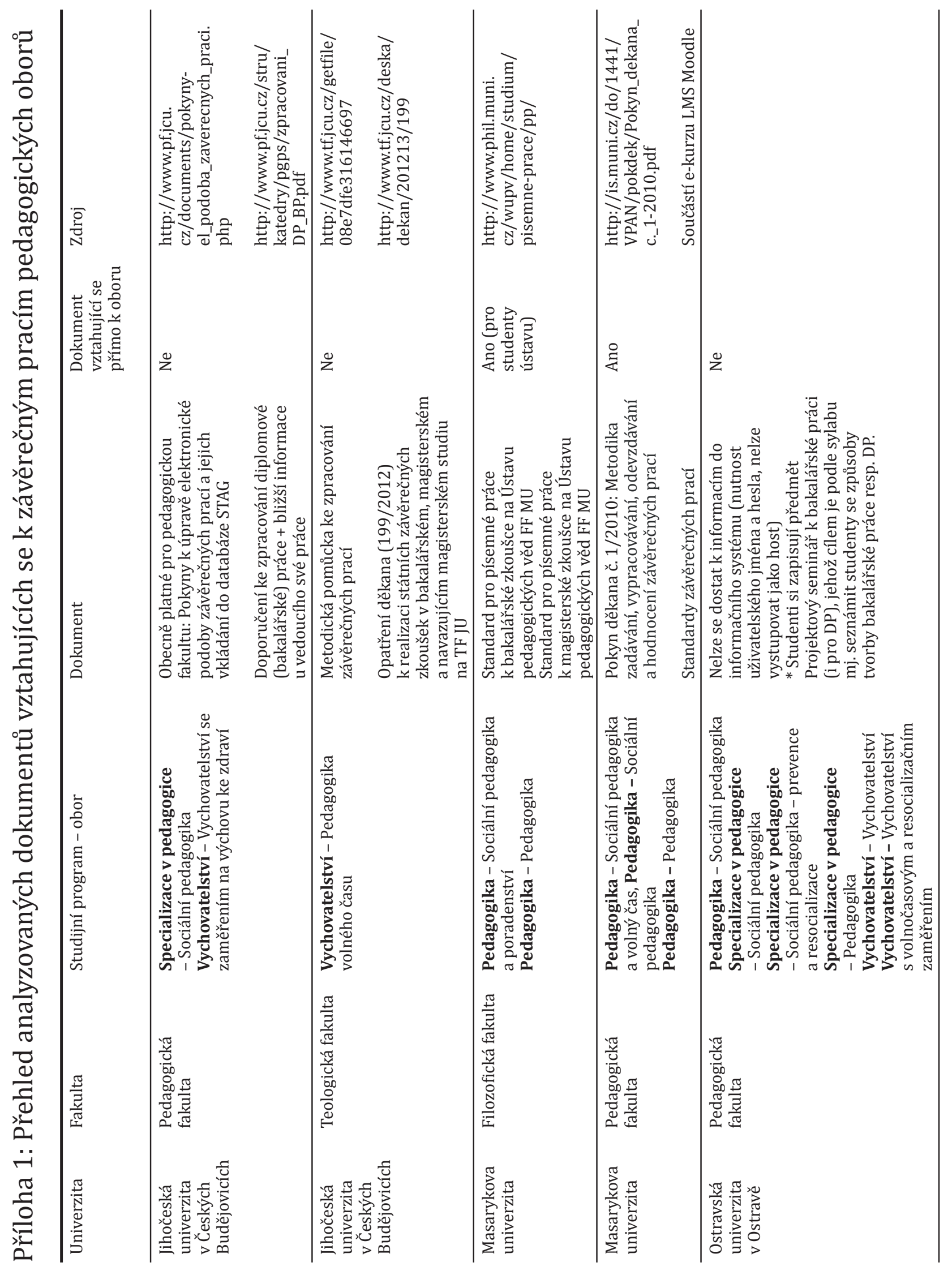




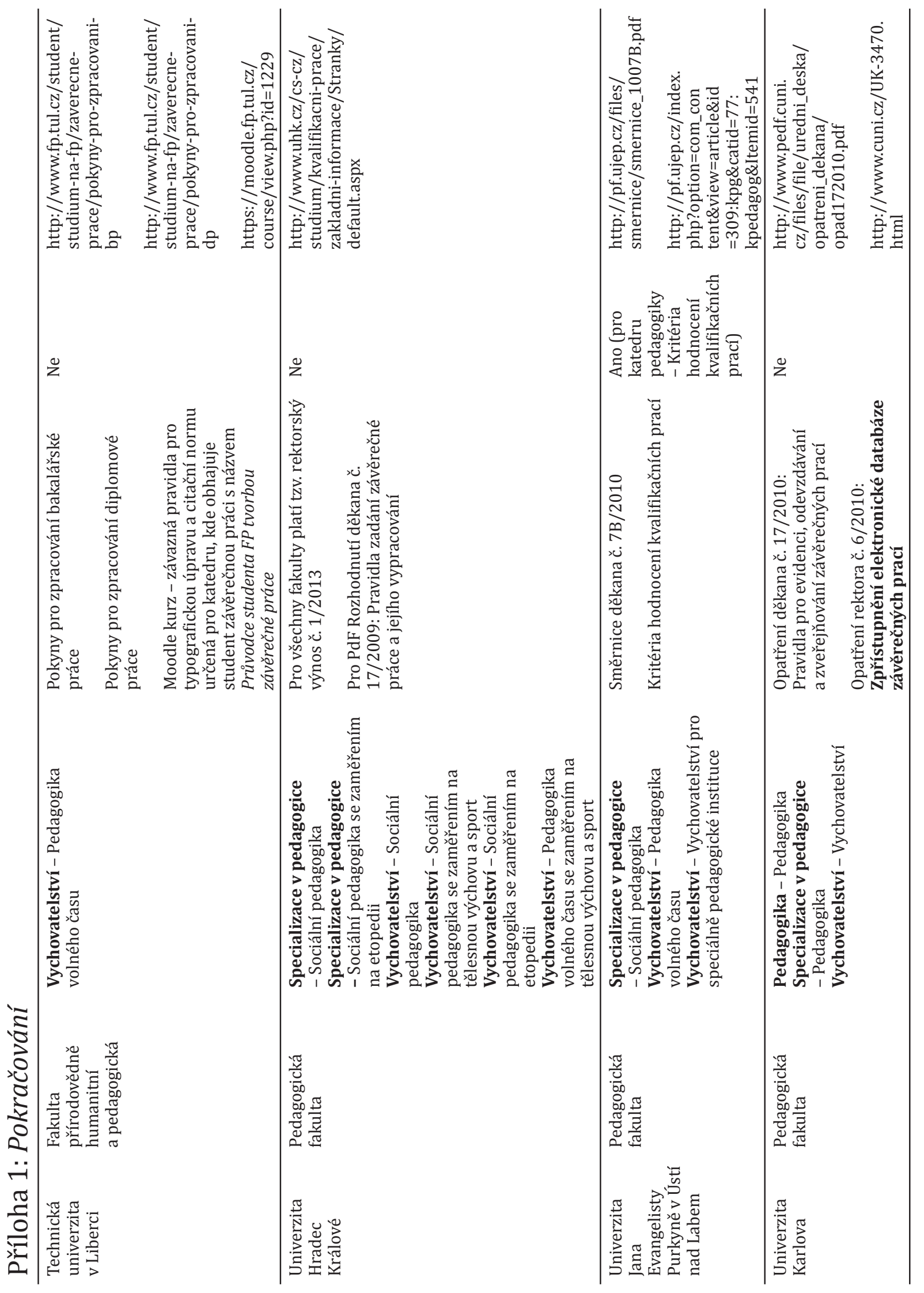




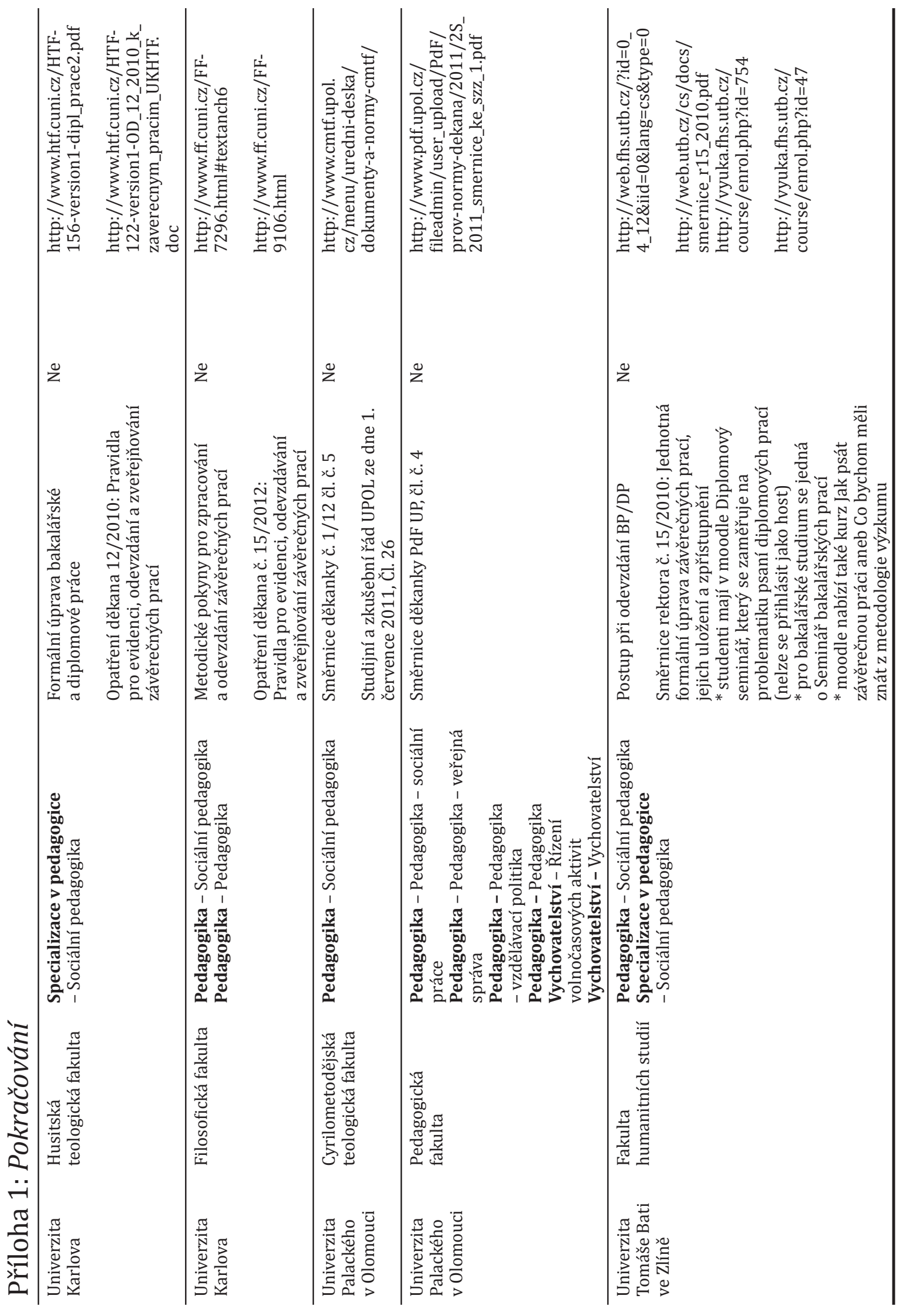

